\title{
Utjecaj koaliranja Hrvatske seljačke stranke sa srpskim radikalima na izborne rezultate 1927. u Bosni i Hercegovini
}

IVICA GLIBUŠIĆ

Sveučilište u Mostaru

Filozofski fakultet

E-pošta: ivica.glibusic@ff.sum.ba
UDK: 324(497.6)"1927"

Izvorni znanstveni rad

Primljeno: 6. svibnja 2019. Prihvaćeno: 21. svibnja 2019.

\section{Sažetak}

U radu se na temelju neobjavljenoga arhivskog gradiva i literature govori o izbornim rezultatima Hrvatske seljačke stranke (HSS) na oblasnim i skupštinskim izborima 1927. na prostoru Bosne i Hercegovine. Koaliranje HSS-a sa srpskim radikalima u Bosni i Hercegovini ostale hrvatske političke stranke i disidenti HSSa dočekali su kao pogodan trenutak da se smanji utjecaj HSS-a među Hrvatima. Hrvatska pučka stranka (HPS), uz pomoć dijela svećenstva Katoličke crkve, najavljivala je pobjedu upravo kroz isticanje HSS-ova sudjelovanja u vlasti sa srpskim radikalima, odustajanje od republikanizma te priznavanje Vidovdanskoga ustava uz optužbe da se Stjepan Radić bori protiv katoličke vjere. Vodstvo HSS-a, dobivši informacije s terena o mogućem osipanju članstva i smanjenju podrške na izborima, primijenilo je agresivniju kampanju obilazeći svako mjesto s potencijalnim svojim biračima kroz utemeljenje novih stranačkih ogranaka. Unatoč sukobu s dijelom svećenstva Katoličke crkve na prostoru $\mathrm{BiH}$ te sabotiranjem stranačkih aktivnosti od srpskih radikala i državnih vlasti te hrvatskih stranaka koje su činile oporbu, HSS je ipak ostvario pobjedu među Hrvatima, odnosno dobio je 
većinsku podršku i na oblasnim i na skupštinskim izborima uz osjetno smanjenje broja glasača, ali s osvojenim brojem mandata Radić nije politički ugrožen, a HSS je i dalje bio vodeća hrvatska stranaka na prostoru Bosne i Hercegovine.

Ključne riječi: Hrvatska seljačka stranka; Hrvatska pučka stranka; Stjepan Radić; izbori; agitacija; oblast; skupština; srpski radikali.

\section{Uvod}

Dok je Stjepan Radić bio u zatvoru, ${ }^{1}$ trajala je intenzivna aktivnost drugih članova stranke na približavanju vladajućem režimu kako bi se postigao dogovor o njegovu puštanju na slobodu, zatim verifikacija zastupničkih mandata i zaustavljanje represije prema stranci. Članstvo i simpatizeri stranke na terenu nisu bili upoznati s pregovorima koje je vodio uži dio vodstva tako da je većina članstva vijest o političkom zaokretu dočekala s nevjericom. Pavle Radić je kao predsjednik Hrvatskoga seljačkog kluba, ${ }^{2} \mathrm{u}$ ime vođe Hrvatske republikanske seljačke stranke (HRSS) Stjepana Radića 27. ožujka 1925. u Narodnoj skupštini pročitao izjavu u kojoj se priznaje stanje definirano Vidovdanskim ustavom s dinastijom Karađorđevića na

1 Pašić - Pribićevićeva Vlada donijela je 23. prosinca 1925. odluku da se Zakon o zaštiti države primijeni i na Hrvatsku republikansku seljačku stranku te da se provede uhićenje vodstva stranke. Odlučeno je da se raspuste sve organizacije HRSS-a. Zabranjeni su svi zborovi, konferencije i rad stranke te izlaženje njezinih novina i publikacija. Provođenje odluke odgođeno je zbog božićnih blagdana, a njezina provedba započela je na Novu godinu 1925. Uhićeni su svi članovi vodstva osim Stjepana Radića koji se skrivao u skloništu u Seljačkom domu u Zagrebu. Otkriven je i uhićen 6. siječnja 1925. Usp. Hrvoje MatKović, Povijest Hrvatske seljačke stranke, Naklada P.I.P. Pavičić, Zagreb, 1999., str. 178.

2 Hrvatsko narodno zastupstvo (narodni zastupnici HRSS-a i Hrvatske zajednice) na zasjedanju u Zagrebu 4. ožujka 1925. zaključilo je da će u Narodnoj skupštini u Beogradu činiti poseban parlamentarni klub koji će se zvati Hrvatski seljački klub. Za predsjednika toga kluba izabran je Pavle Radić, za potpredsjednika Ivica Lorković, a za tajnike su birani Nikola Precca i Albert Bazala. Vidi: Rudolf HoRvat, Hrvatska na mučilištu, Školska knjiga, Zagreb, 1992., str. 244. 
čelu. Stranka mijenja ime u Hrvatska seljačka stranka (HSS). ${ }^{3} \mathrm{Hr}-$ vatska pučka stranka (HPS) optužila je Radića da je iznevjerio svoj program, pa i onaj koji je utanačio s blokovskim strankama, odnosno da je poput Svetozara Pribićevića postao unitarist i centralist, a sve bez znanja zastupnika Hrvatskoga seljačkog kluba i bez odobrenja hrvatskoga naroda. Nadalje, optužuju ga za narušavanje dobrih odnosa s Katoličkom crkvom i Rimom radi uspostave jedne vjere. ${ }^{4}$ Objašnjavajući svoj zaokret Radić kaže da stranka koja ima na trima izborima većinu unutar hrvatskoga biračkog tijela treba sudjelovati u vlasti i u donošenju važnih političkih odluka a ne svoju politiku bazirati samo na deklaracijama, programima i oporbenom djelovanju. Smatrao je kako su Hrvati predugo u oporbi i da se to stanje mora promijeniti. ${ }^{5}$ Posebno je bila znakovita konstatacija koju je Radić izrekao pred Trumbićem, koji ga je kritizirao zbog približavanja radikalima: "Moraš gaziti i u govnima kada nema drugog načina da dođeš do svog cilja". ${ }^{6}$ Ulazak Stjepana Radića u Vladu7 Kraljevine Srba, Hrvata i Slovenaca (Kraljevina SHS) bio je politički manevar kako bi učvrstio svoju stranku nakon teških progona. Iako su mnogi tada smatrali da je njegov sporazum sa srpskim radikalima političko

3 H. Matković, nav. dj., str. 191. Usp. Ivica Glibušić, "Reagiranje Hrvata iz Bosne i Hercegovine na Radićevo približavanje srpskim radikalima", u: Motrišta - Časopis za kulturu, znanost i društvena pitanja, 83-84, Mostar, 2015. str. 69.

4 "Kad vjetrogonja narod vodi...", u: Narodna sloboda, 37, Mostar, 18. rujna 1925., str. 1.

5 Objašnjavajući svoj zaokret Radić kaže: "Stranka koja ima pored tri izbora većinu, ona se ne može jednostavno zadovoljiti programom, deklaracijama, izjavama ona je dužna, i to su svi od nas zahtijevali, da sudjeluje u vladi. Što je onda bilo najpotrebnije, ona je dužna primiti se parlamentarnog rada ako je to moguće. 75 godina mi smo Hrvati u opoziciji netko je morao biti na vlasti. A tko je to bio? ovakvi kakvi se sada tamo (u opoziciji) krevelje. I ja sam kazao. Gospodo, ako mi ostanemo i dalje u opoziciji mi ćemo se odučiti stvarati, mi ćemo se priučiti samo prigovarati. Opasno je to za stranku i za narod, da izgubi svaki doticaj sa vlašću i odgovornošću..." LJubomir AnTić, "Hrvatska federalistička stranka", u: Radovi Zavoda za hrvatsku povijest Filozofskog fakulteta Sveučilišta u Zagrebu, vol. 15, No. 1, Zagreb, 1982., str. 181.

6 Isto, str. 168.

7 Pregovori oko suradnje i ulaska u Vladu Kraljevine SHS intenzivirani su nakon verifikacije radićevskih mandata. Pavle Radić započeo je službene pregovore s Pašićevim radikalima 2. srpnja 1925., a osim njega na tom sastanku u izaslanstvu HSS-a bili su Benjamin Šuperina i Nikola Nikić. Usp. H. MATKović, nav. dj., str. 197. 
Ivica Glibušić - Utjecaj koaliranja Hrvatske seljačke stranke...

samoubojstvo, ipak se na kraju pokazalo da je Radić jakom stranačkom promidžbom uspio uvjeriti Hrvate i dio muslimana u $\mathrm{BiH}$ da je taj njegov čin bio neophodan. Radić je kao državni ministar ${ }^{8}$ uvelike radio na promidžbi svoje stranke i seljačke ideje za izbore 1927., a tu je promidžbu upravo temeljio na sukobljavanju sa svojim koalicijskim partnerom Narodnom radikalnom strankom (NRS). ${ }^{9}$ Previranja u vodstvu HSS-a u BiH dolaze u središte zanimanja, posebice kada je riječ o sukobljavanju Nikole Nikića i Stjepana Radića te drugih protivnika Radićeva pravca političkoga djelovanja.

\section{Oblasni izbori u Bosni i Hercegovini}

Pripreme za izbore 1927. u BiH, a posebno u Mostarskoj oblasti, bile su oštrije nego na prethodnim izborima. HPS se nadao da će napadajući Radića i HSS zbog koalicije sa srpskim radikalima hrvatsko pučanstvo u Bosni i Hercegovini uglavnom prijeći na njihovu stranu. Tako je HPS na naslovnici Narodne slobode, stranačkoga glasila za Hercegovinu, Hrvatima uputio poziv da na sljedećim izborima ne glasuju za Radića navodeći kako on i radikali već godinu i pol vladaju zemljom, zajednički dogovaraju činovništvo, određuju poreze i cijenu duhana. Posebno se napadaju HSS-ovi prvaci u Mostarskoj oblasti - Bariša Smoljan i Nikola Precca. HPS u svojoj kampanji protiv HSS-a konstantno ističe da je Radić prišao Starokatoličkoj crkvi, što je protivno interesima katolika u Hercegovini. ${ }^{10}$ Kada je riječ o

8 Pregovori HSS-a i NRS-a rezultirali su 14. srpnja 1925. potpisivanjem dokumenta pod nazivom Akt sporazuma narodne radikalne stranke $i$ Hrvatske seljačke stranke. Na osnovi propisanoga sporazuma Nikola Pašić podnio je ostavku ali istovremeno dobio mandat za sastavljanje nove vlade. Dana 18. srpnja 1925. formirana je radikalsko-radićevska vlada u kojoj su bila četiri predstavnika HSS-a: Pavle Radić - ministar agrarne reforme, Benjamin Šuperina - ministar pošta i brzojava, Nikola Nikić - ministar šuma i ruda te Ivan Krajač - ministar trgovine i industrije. HSS je dobio i tri mjesta državnih podtajnika, a Stjepan Radić ulazi u Vladu na mjesto ministra prosvjete 18. studenog 1925. Usp. R. HoRvat, nav. dj., str. 299.

9 Usp. I. GLibušić, nav. dj., str. 71.

10 Narodna sloboda (glasilo HPS-a) navodi da je Jozo Jukić, jedan od glavnih Radićevih pobornika u Brotnju, poslao simpatizerima HSS-a jedan paket sa starokatoličkim brošurama i pismom u kojem, između ostaloga, piše: "Vi ste sigurno čuli o našem narodnom crkvenom pokretu, a ja ti po želji šaljem nekoliko knjižica i letaka da ih razdijeliš među naše ljude iz kojih ćete uvidjeti poredak i upravu hrvatske starokatoličke crkve s rimokatoličkom. Čim vas bude 
Radićevim stavovima o Katoličkoj crkvi, oni se mogu povezati kao plod političke borbe protiv dijela katoličkoga svećenstva koje je podržavalo HPS kao izravnoga konkurenta za hrvatske glasače. Cesto su te izjave bile kreirane prema dnevnopolitičkim potrebama i glasačima koji ga slušaju. ${ }^{11}$ Osim stranačkih novina nema dodatne potvrde o organiziranom sudjelovanju HSS-ovih predstavnika na širenju Starokatoličke crkve u Mostarskoj oblasti. Nakon ulaska u vlast Radić je u svojim istupima nagovještavao smjer svoga političkog djelovanja. To se odmah vidjelo na prvom Radićevu javnom političkom nastupu kada je kao ministar prosvjete u Subotici 16. siječnja 1926. istaknuo da su porezi u državi preveliki i da ih nije u stanju podnijeti Vojvodina a kako će onda siromašna područja kao Bosna i Hercegovina te Dalmacija koje su gospodarski slabije razvijene a ovise o poljoprivredi. ${ }^{12}$ Svjestan teškoga stanja u stranci Radić se nakon ulaska u vlast odlučio na provođenje jače izravne kampanje među stanovništvom Bosne i Hercegovine i južne Dalmacije. Nakon boravka u Subotici otputovao je u Sarajevo, a nakon toga kroz Hercegovinu u Dubrovnik. Radić je tijekom 1926. u Bosni i Hercegovini boravio pet puta, a sve s ciljem kako bi konsolidirao stranku i učvrstio svoje članstvo. Pri njegovu dolasku u Bosnu i Hercegovinu dočekuju ga stranački ljudi u Brodu, Derventi, Doboju, Maglaju, Zavidovićima, Žepču, Zenici, Lašvi, Visokom, Sarajevu, Mostaru i drugim mjestima. ${ }^{13}$ Dana

barem 10 pristaša, izaberite privremeni odbor koji neka stupi sa našim odborom u dopisivanje, za dalje upute i informacije o ovom se obrati i na zauzetne poslanike na Barišu Smoljana i Preccu, koji će vam, uvjeren sam, lijepih uputa dati, tim prije jer su oni o tom dosta čuli u Ministarstvu vjera pa bi Vam dosta mogli pomoći osobito za osnutak hrvatske starokatoličke župe u Brotnju." "Hrvati Hercegovci", u: Narodna sloboda, 4, Mostar, 20. siječnja 1927., str. 1.

11 Jedan od Radićevih stavova o osnivanju nacionalne crkve: "Znate po mom mišljenju je klerikalizam tolika opasnost, da se naš hrvatski narod neće nikada pravo sliti sa srpskim, dok se Hrvati ne oslobode Rima i to posvema. Ne mogu Hrvati u pravoslavlje - to nije potrebno, jer bi tu bile odmah velike i jake kontrakcije. Ali ja sam uvijek o tom razmišljao, da bi trebalo stvoriti hrvatsku crkvu, nezavisnu od Rima, nacijonalnu. Možda će vremenom biti moguće upotrebiti za to starokatoličku hrvatsku crkvu". Zlatko Matıjević, U sjeni dvaju orlova, Golden marketing - Tehnička knjiga, Zagreb, 2005., str. 214.

12 R. Horvat, nav. dj., str. 302. Usp. Franko MirošEvić, "Radićevi govori u Dalmaciji 1926.", u: Radovi Zavoda povijesnih znanosti HAZU, 50, Zadar, 2008., str. 290.

13 "Svečani pohod predsjednika HSS u Herceg Bosnu i Dalmaciju", u: Dom, 5, Zagreb, 3. veljače 1926., str. 1. 
Ivica Glibušić - Utjecaj koaliranja Hrvatske seljačke stranke...

31. siječnja 1926. Radić stiže u Sarajevo i svojim nastupima pokušava pridobiti muslimansko stanovništvo za podršku svojoj stranci i politici govoreći kako je potrebno gradove u Bosni i Hercegovini učiniti središtima privrede. Pri tome se osvrnuo na geografsko jedinstvo Bosne i Hercegovine i Hrvatske rekavši kako su "Hrvati iz Dalmacije i Slavonije obuhvatili Bosnu u naručju s lijeva i desna". ${ }^{14}$ Na putu prema Dubrovniku Radić je imao javne nastupe u Mostaru, Čapljini i Gabeli. U Mostaru je priređen svečani doček na željezničkoj stanici na kojemu je nazočilo više stotina ljudi. Na javnom nastupu u Mostaru osudio je zapostavljanje Hrvata govoreći kako ih nema u vlasti a niti u državnim organizacijama koje su imale svoje ispostave na lokalnoj razini. Radić navodi: "Vidite u Bosni nema ni jednog velikog župana Hrvata, a u Beogradu ni jednog direktora". Mostarsko javno obraćanje bilo je naznaka velike konfrontacije sa srpskim radikalima i mogućnost prijevremenih izbora. Objašnjavajući svoj ulazak u vlast Radić je istaknuo kako bit vlasti nije ministarska fotelja nego "izvršavanje teške domovinske zadaće". Smatrao je da je i za Srbe, zbog mira i napretka u zemlji, dobro provođenje jednakopravnosti za sve narode. Radić navodi: "Ako ležeš pod Srbinom, pregazit će te, ali ako ustaneš poljubit će te". ${ }^{15}$ Nakon toga održao je i javni nastup u Čapljini gdje je, osim Hrvata, bio nazočan i velik broj muslimana. U svome govoru opovrgnuo je, kako se navodi, da je Pašić sporazum s HSSom morao potpisati, dodavši da je razlog potpisivanja toga sporazuma taj što je uvidio da se silom ne može vladati. ${ }^{16}$ Nakon Ćapljine Radić je stigao u Dubrovnik gdje je pred crkvom svetoga Vlaha održao govor pred članstvom i simpatizerima HSS-a istaknuvši da se državom ne može upravljati odozgor (centralistički), a niti silom kundaka i pušaka. Prema Radićevu mišljenju jedino je rješenje uvođenje "seljačke demokracije". ${ }^{17}$ Radić je i na ovome skupu objašnjavao razloge ulaska u vlast odnosno sporazum s radikalima. Cilj je, navodi Radić, da se Hrvati slobodno razvijaju i da ostanu ono što jesu, vjerojatno aludirajući na težnje velikosrpske politike da se katolici u Dubrovniku izjasne po nacionalnosti Srbima, a Dubrovnik postane tzv. srpska Atena. Za Srbe Radić kaže da su Srbi, i da ih Hrvati najviše vole kada kažu da su Srbi. Radić nastavlja: "mi njih najvolimo kad

14 R. Horvat, nav. dj., str. 305. Usp. F. MirošEvić, nav. dj., str. 291.

15 F. Mirošević, nav. dj., str. 291.

16 Isto.

17 Isto, str. 292. 
nam kažu da su Srbi. Čim počnu "jugovati" mi velimo da su počeli "ludovati", jer se bojimo prevare. Oni će govoriti da su Jugoslaveni a ipak će srbovati. Mi hoćemo čiste račune. Vi Srbi, a mi Hrvati. Jugoslaveni možemo biti u pravoj Jugoslaviji zajedno s Bugarima". ${ }^{18} \mathrm{Na}-$ kon boravka u Dubrovniku Radić se ponovno vraća u Čapljinu pa u Ljubuški. U Čapljini je govorio o potrebi pravednije raspodjele novca, uređenju države, a posebno je napao ministra financija Milana Stojadinovića da se ne brine o seljacima i njihovim potrebama a vodi računa o ruskim migrantima. Objašnjavajući razlog ulaska u Vladu, Radić ističe da je to bila potreba kako radikali ne bi radili što hoće. ${ }^{19}$ Nakon boravka u Čapljini održao je govor u Ljubuškom pred $5000^{20}$ ljudi, a nakon toga nastavio put prema Lovreču, Dugopolju, Dicmu i Imotskom. ${ }^{21}$ U Narodnoj slobodi od 20. siječnja 1927. u tekstu "Hrvati Hercegovci" upućen je poziv da se na izborima za oblasne skupštine (23. siječnja 1927.) izjasne odobravaju li tadašnje stanje i upravu ili ne odobravaju. Napadi su upereni protiv NRS-a i HSS-a koji zajednički vladaju državom. ${ }^{22} \mathrm{U}$ istom broju Narodne slobode u tekstu "Hrvatski seljački narode" Radića i HSS optužuje se da su pogazili svoja obećanja vezana za seljačku republiku. Glasače se upozorava da ne zaborave 27. ožujka 1925., kada je HSS kukavički priznao velikosrpski "Vidovdanski ustav" i time premoć Srba nad Hrvatima. ${ }^{23} \mathrm{Na}-$ rodna sloboda tvrdi da sve više Hrvata odstupa od Radića i prilazi HPS-u, a samoga Radića optužuju za tri grijeha: nametanje tereta narodu, pokušaj prodavanja katoličke vjere i izbacivanje križeva iz škola. ${ }^{24}$ Radić, svjestan napada od hrvatskih oporbenih stranaka i dijela katoličkoga svećenstva, u svome govoru u Imotskom napada socijaliste i druge "koji ne vjeruju u Boga i ne priznaju narodnost". Posebno naglašava kako treba vjerovati u Boga i da su zločinci oni koji kažu da će ih on privesti na pravoslavlje. ${ }^{25} \mathrm{Na}$ ovaj način, u izravnom obraćanju narodu, Radić je demantirao optužbe koje su ga do-

18 Isto, str. 293.

19 Isto, str. 294.

20 Rudolf Horvat navodi da je na skupu bilo oko 10.000 ljudi. Vidi: R. Horvat, nav. dj., str. 306.

21 F. Mirošević, nav. dj., str. 295.

22 "Hrvati Hercegovci", u: Narodna sloboda, 4, Mostar, 20. siječnja 1927., str. 1.

23 Isto.

24 "Izborno kretanje", u: Narodna sloboda, 49, Mostar, 1926., str. 2.

25 F. Mirošević, nav. dj., str. 295. 
Ivica Glibušić - Utjecaj koaliranja Hrvatske seljačke stranke...

vodile u sukob s Katoličkom crkvom i vjernicima katolicima. U cilju predizborne kampanje, novine su kao udarne vijesti objavljivale one o prelasku pojedinaca ili stranačkih odbora HSS-a u pojedinim mjestima u HPS. U novinama Sloga objavljen je članak s naslovom "Hercegovački Hrvati prelaze radikalnoj Stranki", gdje stoji kako mnoga hrvatska sela prelaze NRS navodeći primjer sela Stubica u srezu Ljubuški, koji pristupaju toj stranci ali ostaju "dobri katolici". ${ }^{26}$ Takvi stavovi bili su zastupljeni kod srpskih političara koji su zastupali velikosrpski program. Negira se postojanje hrvatske nacije ali se daje pravo izjašnjavanja vjeroispovijesti. ${ }^{27}$ Također, u novinama Sloga objavljen je članak pod naslovom "Organiziranje N.R.S. u Šurmancima" u kojemu stoji kako je ta stranka u Čitluku i Rakitnu ostvarila zapažen rad na primanju novih članova u svoje redove. ${ }^{28} \mathrm{U}$ tekstu pod naslovom "Agitacija g. S. Radića po Hercegovini", zamjera se Radiću na kampanji u Hercegovini u kojima je isticao da su Srbi podjarmili Hrvate, a posebno na javnim skupovima u Konjicu i Mostaru. ${ }^{29}$ Kada je riječ o objavljivanju masovnoga prelaska Hrvata u NRS ili neku drugu stranku, to je bila strategija vođenja kampanje kako bi se i druge potaknulo da učine isto. Međutim sami rezultati na terenu bili su zanemarivi. Najveća posljedica Radićeve olako provođene politike i njegovih nekontroliranih ispada, navodi HPS, jest da su se hrvatski zastupnici razjedinili u dva tabora. Radić je htio rascjepkati radikale, a to se dogodilo njegovoj stranci. Izražava se bojazan koliko će zastupnika Nikola Nikić ${ }^{30}$ povući za sobom, a to bi značilo samo

26 "Hercegovački Hrvati prelaze radikalnoj Stranki", u: Sloga, 41, Mostar - Dubrovnik, 14. kolovoza 1926., str. 1.

27 Ante Nazor, "Kontinuitet velikosrpske ideologije kao uzrok rata u Hrvatskoj 1990-ih", u: Vukovar '91. - istina i/ili osporavanje (između znanosti i manipulacije), Zbornik radova, Institut društvenih znanosti Ivo Pilar, Zagreb - Vukovar, 2013., str. 38.

28 "Organiziranje N.R.S. u Šurmancima", u: Sloga, 41, Mostar - Dubrovnik, 14. kolovoza 1926., str. 2.

29 "Agitacija g. S. Radića po Hercegovini", u: Sloga, 46-47, Mostar - Dubrovnik, 25. studenog 1926., str. 1.

30 Unutar HSS-a dogodile su se podjele. Skupina okupljena oko Nikole Nikića, ministra HSS-a, nije se slagala s Radićevim političkim djelovanjem. Nikić je bio povezan s dvorom i radikalskim političarima što je poticalo njegove ambicije za važnijom ulogom u državnoj politici. Na sjednici Hrvatskoga seljačkog kluba 7. srpnja 1926. isključen je iz stranke. Već 12. srpnja u skupštini sa svojom skupinom osniva disidentski Klub Hrvatske seljačke stranke. Nikić podnosi ostavku na ministarsko mjesto 7. listopada 1926. Od potpisivanja 
slabljenje hrvatskih pozicija, a dala bi se prilika Pašiću da bez smetnje i dalje provodi svoju velikosrpsku politiku. ${ }^{31}$ Radićevo približavanje radikalima HSS-ove pristaše u Hercegovini dočekale su s nevjericom. Postavljalo se pitanje o opravdanosti žrtava zbog potpore Radiću. Svojim aktivnim radom HSS-ovo hercegovačko vodstvo za kratko je vrijeme uspjelo spriječiti potpuno rasulo unutar stranke. Unatoč takvim događanjima, HPS nije iskoristio trenutak HSS-ove slabosti kako bi privukao sve razočarane u Radićevu politiku što će se pokazati i na sljedećim izborima. Odnosi u HSS-u poljuljani su, a Nikić je gradio svoju promidžbu izjavljujući da će na osjetljivom terenu Hercegovine omogućiti sadnju tri milijuna strukova duhana više od dotadašnje sadnje. ${ }^{32}$ Radić je još 21. lipnja 1926. u Sarajevu izjavio da više ne računa na Nikića i njegovu skupinu. Unatoč dobroj promidžbi u liberalnom hrvatskom glasilu Jugoslavenski list, Nikić nije bio dobro prihvaćen kod članstva HSS-a u Bosni, ali je u Zenici, Travniku, Busovači i Sarajevu imao potporu pojedinih župnika koji su bili nezadovoljni odnosima Stjepana Radića prema ulozi Katoličke crkve u javnome životu. Međutim, to nije dalo rezultata jer je Radić dobio veliku potporu prilikom posjeta središnjoj Bosni. ${ }^{33}$ Previranja u HSS-u dala su naslutiti da će sljedeća predizborna kampanja biti oštra. Bilo je potrebno stranku učvrstiti na samome terenu što bi se trebalo postići temeljitijim radom stranačkih ogranaka. Kotarska organizacija je 19. travnja 1926. u Čapljini održala izvanrednu skupštinu HSS-a na kojoj su nazočili i izaslanici iz istočnoga dijela Hercegovine. Jednoglasno je zaključeno da se pozdravi predsjednikov rad na suzbijanju korupcije i da mu se ukaže apsolutno povjerenje u vođenju hrvatskoga seljačkog naroda, a osuđen je izdajnički rad Nikole Nikića, Tome Kovačevića i njihovih istomišljenika. Tadašnju kotarsku organizaciju u Čapljini predstavljali su tajnik Salem Metiljević i predsjednik Mijo Jakiša. Potpora Stjepanu Radiću i HSS-u stigla je i iz konjičke kotarske organizacije, od predsjednika Stjepana Anđelića te tajnika Stjepana Jurića. U isto vrijeme kada su unutar HSS-a nastale

sporazuma s radikalima u Narodnoj skupštini smanjio se broj zastupnika HSS-a: 1925. istupilo je 11 zastupnika, a 1926. još osam zastupnika. Usp. H. MATKović, nav. dj., str. 210-211.

31 "Pastirsko pismo presvj. mostarskog biskupa A. Mišića", u: Narodna sloboda, 5, Mostar, 1926., str. 1.

32 Tomislav Išek, Djelatnost Hrvatske seljačke stranke u BiH do zavođenja diktature, Svjetlost, Sarajevo, 1981., str. 263.

33 Isto. 
Ivica Glibušić - Utjecaj koaliranja Hrvatske seljačke stranke...

podjele, Radiću je stigla potpora od ljubuške kotarske stranačke organizacije, ${ }^{34}$ a potom i od šest organizacija broćanskoga kraja, a osuđeni su izdajnički koraci pojedinih zastupnika. Brzojave potpore potpisali su Jozo Jerkić i Stojan Džogić. ${ }^{35}$ Radi popravljanja stanja na terenu među svojim pristašama, HSS je tijekom 1926. krenuo u veliku kampanju učvršćivanja stranke za oblasne i skupštinske izbore. Osnivane su nove organizacije HSS-a, a radilo se i na učvršćivanju postojećega stanja u već formiranim organizacijama. Tako je u Ravnom 25. srpnja 1926. održana HSS-ova skupština koju je otvorio Boško Burić, a sudjelovao je Nikola Precca koji je govorio o hrvatskom seljačkom pokretu i seljačkom programu te o narodnom sporazumu između Hrvata i Srba. Posebno je napadao policijske zapovjednike koji su zajedno sa žandarmerijom i dalje terorizirali hrvatski narod. U Ljubinju je izabran stranački mjesni odbor, a zastupnik Nikola Precca je 6. srpnja 1926. središnjici podnio izvješće o radu stranke u kotaru Ljubinje. U izvješću se potvrđuje da je u kotaru, u kojemu su na prošlim izborima dobili oko 1000 glasova, osnovana još jedna stranačka podružnica. ${ }^{36}$ Zbog neslaganja s radom Radića i kasnijim njegovim izlaskom iz Vlade, HSS su počeli napuštati zastupnici i državni službenici a među njima jedan od najutjecajnijih bio je Nikić koji je svojim radom pokušao destabilizirati HSS u Bosni i Hercegovini. ${ }^{37}$ Nakon Radićeva putovanja u Bosnu i Hercegovinu i Dalmaciju došlo je do burne reakcije u Beogradu i to zbog iznesenih stavova na javnim okupljanjima, pa je 2 . veljače 1926. održana sjednica radikalskoga kluba na kojoj je Radić optužen za hrvatski nacionalizam. Radikali smatraju da je Stjepan Radić odstupio od izjave koju je Pavle Radić dao u Narodnoj skupštini ocijenivši da Radić već sada vodi predizbornu kampanju. ${ }^{38}$ Osim radikala, tisak u Srbiji također je napao Radića zbog njegovih istupa. Hrvatski je tisak o navedenim događanjima drugačije izvješćivao. Tako je primjerice zagrebački Jutarnji list 3. ožujka 1926. pisao kako nema ništa sporno u

34 "Brzojavi i pismene izjave povjerenja predsjedniku HSS", u: Dom, 16A, Zagreb, 22. travnja 1926., str. 2-3.

35 "Brzojavi i pismene izjave povjerenja predsjedniku HSS", u: Dom, 17, Zagreb, 28. travnja 1926., str. 17.

36 "Iz Hrvatske seljačke stranke", u: Dom, 31, Zagreb, 4. kolovoza 1926., str. 4.

37 SuZAna LEČEK, "Problem gradske (samo) uprave u Slavonskom Brodu 1918. 1941.", u: Časopis za suvremenu povijest, 1/2013., Zagreb, str. 20.

38 R. Horvat, nav. dj., str. 307. Usp. F. MirošEvić, nav. dj., str. 296. 
Radićevim govorima po Bosni i Hercegovini i Dalmaciji. ${ }^{39}$ Očito je Beograd bio iznenađen podrškom koju je Radić dobio na svome putovanju i zagovaranju novih izbora za koje radikali nisu spremni a koje je Radić priželjkivao. Kako bi razjasnio svoje nastupe u Bosni i Hercegovini i Dalmaciji, odnosno iznesene stavove koji su se odnosili na uređenje države i općenito odnos vlasti prema narodu, Radić je 10. veljače 1926. došao u Beograd. Prije toga (4. veljače 1926.) Pavle Radić je Nikolu Pašića upoznao s putovanjima Stjepana Radića po Bosni i Hercegovini i Dalmaciji. Također, u međuvremenu je u radikalskim krugovima dogovoreno i da se razgovara s Nikolom Nikićem koji je primljen u audijenciju kod kralja 7. veljače $1926 .{ }^{40} \mathrm{Na}$ sastanku u Beogradu 7. veljače Radić je Pašiću razjasnio poruku svojih govora u Bosni i Hercegovini i Dalmaciji a posebno onaj u Sarajevu o opredjeljivanju muslimana. ${ }^{41}$ Stjepan Radić je napravio vješt manevar pa je u svome stranačkom glasilu Dom istaknuo da su ga druge novine krivo interpretirale kada je riječ o javnim istupima u Bosni i Hercegovini i Dalmaciji. Bura oko njegovih govora nije se brzo stišala jer je uslijedila sjednica Ministarskoga savjeta 13. veljače 1926. na kojoj se Radić očitovao i otklonio dvojbe koje su se pojavile u javnosti. Rezultat toga je odluka Ministarskoga savjeta o objavljivanju teksta sporazuma HSS-a i radikala od 14. srpnja $1925 .{ }^{42}$ Vlada je bila uzdrmana ne zbog Radića koliko zbog otkrivene zloporabe u državnim nabavkama u koje je bio umješan sin Nikole Pašića, što je rezultiralo padom Vlade radikalno-radićevskoga sporazuma. Pašić je 4. travnja 1926. odstupio, a novu Vladu formirao je Nikola Uzunović koji je obnovio radićevsko-radikalnu koaliciju. ${ }^{43}$ Međutim, unatoč novoj Vladi i pokušaju smirivanja stanja u državi Radić je nastavio napadati centralizam iako je bio dio vlasti, a posebno je bio oštar na skupu u Pakracu 11. travnja 1926. kada je napao radikalske ministre

39 F. MirošEvić, nav. dj., str. 297.

40 Isto, str. 298.

41 Nakon sastanka s Pašićem, Radić je iznio svoje tumačenje govora u Sarajevu: "Bitno je u mojem govoru u Sarajevu bilo, da se bosanski muslimani moraju konačno opredijeliti za Hrvate ili Srbe. Jugoslavenstvo to je jedan švindl (varka), kojim se kod nas koriste svi anacijonalni elementi. Nema direktnog prijelaza u Jugoslavenstvo. Mi smo Srbi, Hrvati i Slovenci, pa je to jedan put, kojim se treba opredijeliti. U interesu cijele države, da se Bosna i Hercegovina kulturno i ekonomski ojačaju. U Hercegovini sam vidio toliko sirotinje i nezaslužene bijede". R. Horvat, nav. dj., str. 308.

42 R. Horvat, nav. dj., str. 308. Usp. F. MirošEvić, nav. dj., str. 299.

43 F. Mirošević, nav. dj., str. 300. Usp. R. Horvat, nav. dj., str. 309-313. 
Ivica Glibušić - Utjecaj koaliranja Hrvatske seljačke stranke...

zbog bahatosti, bogaćenja, pri tome posebno ističući potrebu borbe protiv korupcije. Ubrzo nakon toga formirana je nova vlada bez Stjepana Radića. ${ }^{44}$

HSS-ova kotarska organizacija u Mostaru je 1. kolovoza 1926. održala redoviti sastanak kojemu su nazočili izaslanici 33 mjesne organizacije i narodni zastupnik Dervo Hadžioman. Na sastanku je izražena potpora Stjepanu Radiću te prihvaćeni zaključci Hrvatskoga seljačkog kluba od 7. srpnja 1926., a koji su se odnosili na isključivanje Nikole Nikića i osudu njegove privatne politike. Bariša Smoljan izvijestio je središnjicu stranke u Zagrebu o održanom sastanku mjesne organizacije u Mostaru na kojemu je izabran novi odbor. ${ }^{45}$ Izaslanici 14 mjesnih organizacija iz okolice Širokoga Brijega održali su zajednički sastanak kojim je predsjedao Marko Zovko, tajnik mjesne organizacije Mokro, koji je naglasio da Nikić vodi posebnu protuhrvatsku i protuseljačku politiku i da je zbog toga isključen iz stranke. Na sjednici je dogovorena reorganizacija mjesnih odbora. $\mathrm{Na}$ Trebinji, u ljubinjskom kotaru, također je osnovana organizacija HSS-a, a skupštinu je vodio Nikola Precca koji je tada obišao poplavljena područja Popova polja, evidentirao štetu i ministru poljoprivrede i voda uputio predstavku da se stradalim seljacima priskoči u pomoć. ${ }^{46}$ Umjesto oslabljen, zbog koalicije s radikalima, HSS je pred izbore 1927. nastupio još snažniji. Unatoč propagandi koju je vodio HPS, došlo je do priključenja dijela članstva Jugoslavenske muslimanske organizacije (JMO) HSS-u, što je bio još jedan prilog jačanju HSS-ove pozicije u Mostarskoj oblasti.

U učvršćivanje stranačkih redova na bosanskohercegovačkom terenu i pridobivanje novih članova uključio se i sam Stjepan Radić koji je održao tri velike skupštine - u Travniku, Zenici i Žepču. Radić je u svome govoru u Travniku istaknuo važnost sudjelovanja žena u javnom životu. "Mi smo u Hrvatskoj metnuli žene na prvo mjesto jer su one to i zaslužile", naglasio je Radić i ukorio muslimane da još vode begovsku politiku u odnosu prema ženama. U Zenici se također zalagao za angažiranje žena u politici i javnome životu naglašavajući: "A još napose pozdravite sve naše drage žene građanke i seljanke,

44 R. Horvat, nav. dj., str. 308-313. Usp. F. Mirošević, nav. dj., str. 306.

45 "Iz Hrvatske seljačke stranke", u: Dom, 36, Zagreb, 8. rujna 1926., str. 4.

46 "Sastanak mjesnih organizacija okolice Široki Brijeg", u: Dom, 30, Zagreb, 1926., str. 5. 
napose naše muslimanke kojih ovdje nema. ${ }^{\text {"47 }}$ Zastupnik Hadžioman izvješćivao je da politika HSS-a među muslimanima dobro kotira, ali samo u onim kotarima i selima u kojima su se u posljednje vrijeme, od ujedinjenja Spahine s Davidovićevom političkom opcijom, održavale stranačke aktivnosti (u mostarskom, stolačkom i nevesinjskom kotaru). Hadžioman ističe da su muslimani u nedoumici i ne znaju kojoj bi se stranci priklonili te je među njima potrebno razviti intenzivnu stranačku promidžbu jer će se u protivnom prikloniti Spahi i demokratima. Unatoč čvrstoći stranačkih redova, Hadžioman upozorava da će zbog nevjerojatne bijede i siromaštva odaziv birača biti slabiji nego na prošlim izborima. Također, rad drugih političkih stranaka, a naročito Pučke, usredotočen je na mostarski i ljubuški kotar. Slab otkup duhana i nečovječno postupanje uprave monopola glavni su aduti u predizbornom agitiranju. Iako su te poteškoće slomile i srpsko pučanstvo, HPS-ovci prelaze preko toga i svoje napade usmjeravaju na HSS. ${ }^{48}$

Radićevi protivnici među hrvatskim političkim strankama radili su na promidžbenoj kampanji kako bi HSS optužili za izdaju zbog koaliranja sa srpskim radikalima. Nikola Mandić i Niko Popović 10. prosinca 1926. održali su sastanak s uglednim Hrvatima i franjevcima u Fojnici s ciljem, kako je naglasio Mandić, osnivanja Nikićeve stranke i njezino jačanje u fojničkom kotaru. Mandić je osudio rad Stjepana Radića "koji Hrvatima donosi više štete nego koristi" te je predložio utvrđivanje liste za oblasnu skupštinu nakon čega su jednoglasno izabrani Andrija Alaupović i Ivo Lovrić. Iako je Mandić predlagao da se zamjenici izaberu iz Busovače i Kreševa, ipak je trebalo čekati suglasnost fra Silvija Frankovića, župnika u Busovači, koji je bio i predsjednik novoosnovane Nikićeve stranke. ${ }^{49}$ Stjepan Radić nazvao je 29. prosinca 1926. u Domu Nikolu Krešića "odmetnikom i dušmaninom HSS-a". Također, i Hakija Hadžić osuđuje Nikića i smatra ga najvećim neprijateljem HSS-a kojemu je jedini cilj cijepanje hrvatskih glasova. ${ }^{50} \mathrm{HSS}$ u završnoj fazi priprema za izbore

47 "Seljačka politika izmiruje sve naše narodne elemente u Bosni da ju učini glavnim izvorom našeg narodnoga bogatstva", u: Dom, 32, Zagreb, 11. kolovoza 1926., str. 1-3.

48 "Sastanci u Hercegovini", u: Dom, 3, Zagreb, 1927., str. 3-4.

49 Arhiv Bosne i Hercegovine (dalje: ABiH), Veliki Župan Sarajevske Oblasti (dalje: VŽSO), POV., 1927., 240, f. 31r i f. 32r.

50 ABiH, VŽSO, POV., 1927., 240, f. 127r-143r. 
Ivica Glibušić - Utjecaj koaliranja Hrvatske seljačke stranke...

dodatno je potaknuo aktivnost svojih predstavnika na lokalnoj razini na prostorima Bosne i Hercegovine. Svim HSS-ovim kotarskim organizacijama 29. studenoga 1926. upućena je obavijest da su izbori za oblasne skupštine raspisani za nedjelju, 23. siječnja 1927. Od 4. do 20. prosinca 1926. trebalo je postaviti kandidacijske liste, a sve kotarske organizacije morale su održati svoje sjednice 5. ili 8. prosinca, a najkasnije 12. prosinca 1926. Na oblasnim izborima u Bosni i Hercegovini HSS je predložio zajednički nastup s JMO, a usuglašeno je da će se zajednički nastupi dogovarati prijateljski te da će HSS prihvatiti suradnju gdje god zajednički istup osigurava veći zajednički uspjeh. Taj zajednički nastup HSS-a i JMO-a, prema mišljenju Stjepana Radića, trebao bi Bosnu i Hercegovinu izvesti iz zapuštenosti i omogućiti joj pravo na gospodarski i prosvjetni razvoj. ${ }^{51}$ Zastupnik HSS-a Dervo Hadžioman posjetio je stolački i dio mostarskoga kotara gdje se upoznao s teškim životom tamošnjega pučanstva. Na tom je putu održao 15 sastanaka, a uslijedio je članski preustroj, što je dovelo do pristupanja lokalnoga stanovništva HSS-u. Meho Rahić iz Bivoljeg Brda, kod Domanovića, pod utjecajem je Derve Hadžiomana iz JMO-a pristupio HSS-u. Promidžbeni sastanak održan je u Lokvama, selu u kojem nije bilo HSS-ove podružnice i u kojem nitko nije na prošlim izborima glasovao za HSS. Nakon toga Hadžioman je održao sastanak i u Crnićima gdje su im se pridružili i predstavnici Aladinića, a među nazočnima je bio i velik broj muslimana. Prema pisanju novina Dom, čapljinski su muslimani prešli u HSS. Peti sastanak održan je u Stocu, a potom u Borojevićima i Pješivcu. Na sastancima su se seljaci tužili na progone i nepravde koje im čini ured za otkup duhana. Sljedeći sastanak održan je u Gnjilištima, a uslijedili su u Višićima, Dračevu, Doljanima, Čeljevu, Staroj Gabeli te u Čapljini i u Trebižatu u Hrvatskoj čitaonici gdje je osuđena Nikićeva politika i politika njegovih istomišljenika. Treba reći da je Trebižat u to vrijeme bio jedno od najnaprednijih hercegovačkih mjesta - imao je čitaonicu, djelovao je tamburaški i pjevački zbor te limena glazba, a mještani su se okupljali oko društva "Hrvatski seljački sokol". HSSovci iz Trebižata na sastanku su izrazili privrženost stranačkoj politici Stjepana Radića. Nakon Trebižata održan je stranački sastanak u Ljubuškom gdje se raspravljalo o stanju u tom kotaru. Sastankom u Ljubuškom završila je promidžbena kampanja u tom dijelu Mostar-

51 "Svim kotarskim organizacijama Hrvatske Seljačke Stranke", u: Dom, 49, Zagreb, 4. prosinca 1926., str. 1. 
ske oblasti. ${ }^{52}$ HSS-u su pristupili i muslimani nevesinjskoga kraja koji su 12. prosinca 1926. potpisali izjavu da napuštaju JMO i pristupaju HSS-u. Izjavu je potpisao 81 musliman. ${ }^{53}$

\section{Rezultati oblasnih izbora}

Prema "Vidovdanskom ustavu", država je bila podijeljena na oblasti koje su se dalje dijelile na manje administrativne jedinice - kotareve i općine. Svaka oblast mogla je imati najviše 800.000 stanovnika. Kralj je 26. lipnja 1922. donio Uredbu o podjeli zemlje na oblasti prema kojoj je država podijeljena na 33 oblasti, no Uredba se počela provoditi tek 1926., a oblasni su izbori raspisani za 23. siječnja 1927. Vodstvo HSS-a je najavljene lokalne izbore shvatilo kao provjeru njegove pozicije u narodu koja će odrediti orijentaciju njihove politike prije sljedećih skupštinskih izbora, jer nezadovoljstvo naroda zbog suradnje s Radikalnom strankom bilo je očito. ${ }^{54} \mathrm{U}$ predizbornoj agitaciji prvaci HSS-a otvoreno istupaju protiv centralizma i posrbljivanja Hrvata što glasačima daje znak da se HSS vraća svojoj staroj politici. ${ }^{55}$

Prema priopćenju Ministarstva unutarnjih poslova, na izborima za oblasne skupštine u svim oblastima HSS postigao je ukupno 264 mandata, a disidenti šest. U Bosni i Hercegovini najviše mandatnih mjesta HSS je dobio u Travničkoj oblasti (11), u Mostarskoj oblasti dobio je 11, u Banjolučkoj šest, u Tuzlanskoj pet i Sarajevskoj tri mandata. ${ }^{56}$ HSS je ukupno u Bosni i Hercegovini osvojio 36 mandata. ${ }^{57}$ Bariša Smoljan izvijestio je stranačku središnjicu da je HSS u čitavoj Mostarskoj oblasti dobio 19.000 glasova. ${ }^{58} \mathrm{Na}$ nekoliko primjera možemo vidjeti izraženu podršku politici Stjepana Radića u Hercegovini. Tako je primjerice, na biralištima u Sovićima i Gorici, u ljubuškom kotaru, od ukupno 913 glasača, glasovalo 828, od toga

52 "Organizacija HSS u Hercegovini i težak život tamošnjeg naroda", u: Dom, 34, Zagreb, 1926., str. 4-5.

53 "Pristup nevesinjskih muslimana", u: Dom, 2, Zagreb, 12. siječnja 1926., str. 3.

54 H. MatKović, nav. dj., str. 213.

55 Isto, str. 214.

56 Isto, str. 215.

57 Usp. H. Matković, nav. dj., str. 215. Usp. R. Horvat, nav. dj., str. 331. Usp. T. IšEK, nav. dj., str. 280.

58 "Najvažniji rezultati županijskih izbora", u: Dom, 4, Zagreb, 1927., str. 3-4. 
Ivica Glibušić - Utjecaj koaliranja Hrvatske seljačke stranke...

je 781 birač glasovao za HSS i 45 za HPS. ${ }^{59}$ Oblasni odbor iz Tihaljine, kotar Ljubuški, gdje su glasovala četiri sela: Tihaljina, Puteševica, Borajna i Dragićina, imao je ukupno 867 glasača od kojih njih 211, zbog lošega vremena i udaljenosti biračkoga mjesta, uopće nije izišlo na izbore. Mnogi birači nisu mogli glasovati zbog netočnih podataka u biračkim popisima. Od 656 birača koji su pristupili izborima HSS je dobio 609 glasova. ${ }^{60}$ Tijekom tih izbora vladajući je režim, slično kao i prije, raznim oblicima prisile pokušao izboriti pobjedu svojih stranaka. Dvadesetak dana prije oblasnih izbora počelo je nasilje. Protiv HSS-ovih pristaša podiže se svojevrsna hajka - uhićeno je više čuvara izbornih kutija, zabranjivana je HSS-ova promidžba, krivotvoreni su izborni rezultati. U izvješću Hrvatskoga seljačkog kluba u vezi izborne korupcije i strahovlade prosvjeduje se da su u biračkim odborima imenovani ljudi slabe ili nikakve izobrazbe, ljudi s kojima radikali mogu lako manipulirati. Mnogi su se HSS-ovci ponovno našli u zatvoru, izborni zapisnici i izborni rezultati krivotvoreni su. ${ }^{61}$ Izborne zloporabe nisu bile evidentne samo u Bosni i Hercegovini, nego i u Srijemu i u Dalmaciji. Zbog toga je HSS odlučio od predsjednika vlade Nikole Uzunovića i ministra unutarnjih poslova Bože Maksimovića, zatražiti da se kazne svi oni koji su prije i za vrijeme izbora postupali protuzakonito. Stjepan Radić je negirao pisanje beogradskih novina da je HSS u Bosni i Hercegovini izgubio dio svojih pristaša, navodeći da je HSS u Bosni i Hercegovini dobio 37 oblasnih mandata, a na zajedničkim listama s JMO-om četiri mandata. HSS je, ističe Radić, sveukupno osvojio 41 mandat, što je za samo šest mandata manje od radikala koji $\mathrm{BiH}$ često proglašavaju čisto srpskom, pa čak i izrazito radikalskom zemljom. ${ }^{62}$ Unatoč dobrim rezultatima u Bosni i Hercegovini, HSS nije bio zadovoljan izbornim rezultatima koji bi, prema Radićevoj ocjeni, bili još bolji da nije bilo nasilja i prijevara. Zbog takvih postupaka vladajućega režima Radić je uložio prigovor Narodnoj skupštini u Beogradu da bi 28. siječnja 1927. ministri, članovi HSS-a, izišli iz vlade. Nakon toga HSS je u Narodnoj skupštini ponovno postao oporbena stranka iako je u nekim krajevima i u Bosni i Hercegovini i u Hrvatskoj imao većinsku vlast. Do povlačenja ministara došlo je nakon predizbornoga i izbornoga

59 Isto.

60 "Oblasni odbor u Tihaljini", u: Dom, 5, Zagreb, 1927., str. 4.

61 "HSS zastupnici protiv izborne korupcije", u: Dom, 5, Zagreb, 1927., str. 1.

62 R. HoRvat, nav. dj., str. 331. 
terora ${ }^{63}$ Bio je to kraj HSS-ove koalicije s radikalima, pa u novoj vladi, formiranoj 1. veljače 1927., više nije bilo HSS-ovih predstavnika. Uz HSS u oporbi su bili Davidovićevi demokrati, Samostalna demokratska stranka (SDS), JMO i HSS-ovi disidenti okupljeni oko Nike Nikića. ${ }^{64}$

Nakon izbora sve su se oblasne skupštine bile dužne sastati 23. veljače 1927., a obvezu sazivanja sjednica imao je najstariji skupštinski zastupnik. Ako se sjednici odazove trećina zastupnika, slijedi polaganje prisege na vjernost kralju, ustavu, narodu i zakonu, a nakon toga tajnim se glasovanjem biraju predsjednik, potpredsjednik i trojica tajnika. Prema uputama o radu oblasnih skupština, isti dan u poslijepodnevnim satima mora biti sazvana druga sjednica na kojoj se biraju tri odbora - za proračun i financije, za oblasne uredbe te za molbe i pritužbe. Odbori se biraju na mandat od četiri godine. Ustavom i zakonskim aktima definirane su mjerodavnosti velikoga župana koji, kao predsjednik vrhovne državne vlasti, ima ovlasti usporedno sa skupštinom, ali ne i iznad nje - veliki župan može predlagati, ali bez skupštinske suglasnosti ne može donositi odluke. ${ }^{65}$

Radić je, nakon iznimno dobrih rezultata na izborima, iznio prijed$\log$ da se svih šest oblasti u Bosni i Hercegovini spoje u jednu što je naišlo na oštru osudu Srba koji su bili apsolutno protiv toga. ${ }^{66}$ Postignuti rezultati na oblasnim izborima dali su jasan signal HSS-u da se, ukoliko žele zadržati postojeće stanje i ostvariti još bolje rezultate na izborima, moraju još aktivnije uključiti u promidžbenu kampanju za skupštinske izbore. Srpske stranke izražavale su nezadovoljstvo oko formiranja oblasnih vlasti u onim oblastima gdje nisu ostvarile zapažen rezultat. Tako su predstavnici Srba izrazili negodovanje što su u formiranoj Oblasnoj skupštini u Mostaru 23. veljače 1927. ostali bez utjecaja. Optužbe su iznijete zbog toga što Srbi nisu ušli ni u jedan Oblasni odbor, a sve se nalazi u Radićevim rukama. ${ }^{67}$ Također

63 Bosiljka Janjatović, Politički teror u Hrvatskoj, 1918. - 1935., Hrvatski institut za povijest, Zagreb, 2002., str. 87.

64 H. MAтKović, nav. dj., str. 216.

65 "Oblasna skupština pravi je gospodarski i kulturni socijalni sabor", u: Dom, 7, Zagreb, 1928., str. 1.

66 "Oblasna skupština u Mostaru", u: Sloga, 6-7, Mostar - Dubrovnik, 26. veljače 1927., str. 1.

67 Isto. 
Ivica Glibušić - Utjecaj koaliranja Hrvatske seljačke stranke...

i predstavnici HPS-a nisu bili zadovoljni postignutim rezultatima. Narodna sloboda objavila je članak pod naslovom "Komunikej zajedničara" u kojem su zajedničari napali Radića zbog suradnje i dogovora da se zajednički bore kako bi Hrvatska dobila svoj sabor, bana, gospodarsku i prosvjetnu samoupravu. Međutim, Pavle Radić je već 27. ožujka 1925. u Narodnoj skupštini dao izjavu kojom prihvaća sve principe radikalske politike. Ta je izjava dana bez odobrenja seljačkoga kluba i zbog toga najavljuje da će se dogoditi rascjep među radićevcima, kojega će svakoga dana sve više napuštati zastupnici ili članovi. ${ }^{68}$

\section{Predizborna kampanja za skupštinske izbore 1927.}

Odbor Narodne skupštine, prema članku 7. Izbornoga zakona, sastao se 22. lipnja 1927. u Beogradu i odredio početak izbornih aktivnosti. Izborni su se popisi i ovaj put radili prema popisu pučanstva iz 1910., pa se u Bosni i Hercegovini biralo 48 zastupnika, u Hrvatskoj i Slavoniji 66, u Srbiji 114, u Dalmaciji 16, u Sloveniji 25, u Crnoj Gori sedam, u Vojvodini 34, u Zagrebu dva, u Beogradu dva, a u Ljubljani jedan. U Bosni i Hercegovini je banjolučki okrug birao 10, bihaćki šest, mostarski sedam, sarajevski i travnički također po sedam i tuzlanski 11 zastupnika. ${ }^{69}$

Nakon HSS-ova prijelaza u oporbu političko stanje u zemlji je za vladu Kraljevine SHS postalo sve složenije jer je uz HSS stvorena jaka oporbena koalicija. Radiću se ukazala mogućnost za suradnju s drugim građanskim grupacijama u Hrvatskoj i Srbiji. ${ }^{70}$ Kako bi se stanje u zemlji promijenilo, bilo je potrebno raspisati nove izbore. Vukičevićeva vlada je za 11. rujna 1927. raspisala nove skupštinske izbore, a Radić je optimistično najavljivao da će dobiti 100 narodnih zastupnika u Banskoj Hrvatskoj, Bosni, Dalmaciji, Sloveniji i Vojvodini, očekujući kako će dobiti i nekoliko mandata u Makedoniji i Srbiji. ${ }^{71}$ Pavle Radić, u govoru u prostorijama društva Trebević 16. svibnja 1927., ističe kako Srbi nikako ne shvaćaju da u ovoj zemlji vlast imaju

68 "Komunikej Zajedničara", u: Narodna sloboda, 17. srpnja 1925., str. 2.

69 "I ovi izbori provest će se po popisu pučanstva od godine 1910.", u: Dom, 28, Zagreb, 1927., str. 3.

70 B. Воваn, "O osnovnim obilježjima 'seljačke države' u ideologiji Antuna i Stjepana Radića", u: Radovi Zavoda za hrvatsku povijest, 13, Zagreb, 1980., str. 69.

71 H. Matković, nav. dj., str. 226. 
Hrvati, Slovenci i Srbi, a ne samo Srbi. Posebno se osvrnuo na štetnu politiku bivših HSS-ovaca ustvrdivši da su radikali kupili Nikića koji radi za njihove interese, a ne za hrvatske. ${ }^{72}$ Policijska direkcija za Bosnu i Hercegovinu u izvješću za kolovoz 1927. navodi kako je Krnjević 20. kolovoza 1927. u Alipašinu Mostu istaknuo da se HSS ne će kandidirati za izbore u Makedoniji jer to ne daju radikali. Napadnut je i Pavao Radić zbog njegova javnog rada navodeći: "A mi nismo sprečavali kada je dr. Milan Srškić dolazio fratrima u Fojnicu na ručak a niti dr. Lazu Markovića kada je u Čitluku uz pomoć fratara agituje među katolicima a fratrima se revanširaju dodjelom ordena". ${ }^{73} \mathrm{Na}$ promidžbenom plakatu HSS-a upućen je poziv u sarajevskom okružju da se podrži lista čiji je nositelj dr. Juraj Krnjević, glavni tajnik HSS-a iz Zagreba, a za kotar Fojnica Stijepo Relota. ${ }^{74}$ Izvršni odbor HSS-a utvrdio je 6. srpnja 1927. nositelje kandidacijskih lista u Bosni i Hercegovini. Nositelji lista po izbornim okruzima bili su: Krnjević za sarajevski okrug, Šutej za tuzlanski, P. Radić za banjolučki, Ivan Čelan za travnički, Dervo Hadžioman za bihaćki i August Košutić za mostarski. Tijekom predizborne kampanje Stjepan Radić je u dva navrata bio u Bosni s ciljem popravljanja ugleda HSS-a. Krajem srpnja 1927. održao je predizborne govore u Bosanskom Brodu, Modranu, Plehanu i Derventi, a krajem kolovoza iste godine u Banjoj Luci. U svojim predizbornim govorima Radić je kritizirao rad vlade. ${ }^{75} \mathrm{U}$ sarajevskom okrugu objavljen je promidžbeni letak namijenjen katolicima i muslimanima Hrvatima čiji je tekst završavao usklikom "Vjera u Boga i seljačko-radnička sloga!"76 Također, objavljen je letak pristaša HSS-a u Hercegovini s nositeljima lista, na čelu s Augustom Košutićem. ${ }^{77}$ HSS je 21. kolovoza 1927. održao skup u Kiseljaku, nakon toga u Busovači, a potom u Fojnici. Zbor je u Fojnici otvorio predsjednik kotarskoga odbora Stjepan Pecirepa. Potom je Krnjević nastojao govoriti o djelovanju Stjepana Radića, no među okupljenima našli su se i nezadovoljnici koji su, podržani fratrima, ometali njegov govor. Uslijed toga došlo je do verbalnoga sukoba između fra Vijeke Kulijera i Krnjevića. Fra Vijeko je dobacio

72 ABiH, VŽSO, POV., 1927., 234.

73 ABiH, VŽSO, POV., 1927., 2342.

74 ABiH, VŽSO, POV., 1927., 1803.

75 Z. Matijević, nav. dj., str. 179-180.

76 ABiH, VŽSO, POV., 1927., 1823, (Letak HSS-a).

77 ABiH, VŽSO, POV., 1927., 1083, f. 53. 
Ivica Glibušić - Utjecaj koaliranja Hrvatske seljačke stranke...

da se predstavnici HSS-a "bore samo za svoj džep", a Krnjević mu je na to odgovorio da "među svećenstvom ima lopova". ${ }^{78} \mathrm{U}$ prepirku se uključuju i ostali franjevci, potpomognuti narodom, te žandari prekidaju zbor kako bi se izbjegli fizički sukobi. Jedna je skupina klicala "Živio Radić!", a druga "Živio Papa!"79 U Kreševu je istoga dana zbog mlade Mise jednoga franjevca bilo okupljeno 2000-3000 seljaka iz fojničkoga i konjičkoga kotara, te je HSS zakazao zbor za 17 sati kako bi iskoristio veliku nazočnost lokalnoga stanovništva. Doznavši za zbor, aktivisti Hrvatske pučke stranke, udruženi s aktivistima Narodne radikalne stranke, tumačili su okupljenima da je potrebno bojkotirati taj HSS-ov skup pa su sudionici proslave napustili grad oko 16 sati. Krnjević je s pratnjom došao u Kreševo, ali ga je dočekalo samo oko 50 ljudi. U razgovoru s njima Šutej je istaknuo da je "danas jasno da su se ujedinili radikali i Koroščevi pučkaši franjevci". 80 U Lepenici (Kiseljak) na Homoljskoj ćupriji u rujnu 1927. održan je zbor NRS-a na koji je došao Ivan Pavičić iz Sarajeva, u pratnji Nike Popovića. Iako je na tom prostoru zanemariv broj stanovnika koji su se izjašnjavali Srbima, ipak je uz pomoć njihovih simpatizera među Hrvatima došlo do promidžbenih sastanaka te stranke. Pavičić je govorio o potrebi zajedništva Hrvata i Srba u jednoj stranci optuživši Stjepana Radića da je vodio štetnu politiku za Hrvate. Iznio je nekoliko optužbi protiv Radića spominjući njegovo zatvaranje, priznanje ustava i borbu za "fotelje". ${ }^{81}$ NRS je održao politički zbor u Polju kod Kreševa 4. rujna 1927. Zbor, na kojemu je bilo oko 1000 ljudi, većinom katolika iz okolnih mjesta, otvorio je Ivo Malenica, koji je potom dao riječ ministru Milanu Srškiću. Na skupu se pozivalo na jedinstvo Hrvata i Srba, a napadala se politika Stjepana Radića. U ime radikala u Kreševu je govorio Ivo Pavičicić ${ }^{82}$ kao Hrvat, a u Fojni-

78 ABiH, VŽSO, POV., 1927., 1810, f. 137r-143r.

79 ABiH, VŽSO, POV., 1927., 1810, f. 137r-143r.

80 ABiH, VŽSO, POV., 1927., 1810, f. 137r-143r.

81 ABiH, VŽSO, POV., 1927., 1810, f. 3.

82 Nakon atentata na hrvatske zastupnike u Narodnoj skupštini sarajevski odvjetnik Ivo (Ivica) Pavičić napustio je Narodnu radikalnu stranku. Nakon njegova istupa NRS napustio je još jedan dio Hrvata iskazavši nezadovoljstvo odnosom beogradskoga režima prema Hrvatima. Pavičić je bio aktivan član radikalne stranke, 1926. optužio je sarajevskoga biskupa Ivana Šarića kako brani Hrvatima da postanu članovi NRS-a, a također da je biskup izrazio nezadovoljstvo zbog njegova teksta u listu Sloboda koji govori o tome da Hrvati trebaju postati članovima NRS-a, okarakteriziravši ga protivnim interesima Hrvata katolika. Vidi: ABiH, VŽSO, POV., 1926., 557. 
ci, Kraljevoj Sutjesci i Kreševu također franjevci, osuđujući politiku Stjepana Radića. ${ }^{83}$ U srpnju 1927. Radikalna je stranka interno radila na prikupljanju novih pristaša iz redova HSS-a. Tako su u Kreševu na promidžbi kod domaćega pučanstva za prelazak u Radikalnu stranku radili Niko Ban i Frano Martinčević, a u Fojnici braća Trogrančić. Također, u Općini Rostovo postao je sve primjetniji prelazak Hrvata u tu stranku. ${ }^{84}$

HPS je u Brestovskom - kotar fojnički, u okviru promidžbene kampanje, održao politički skup 8. rujna 1927. Iz sačuvanoga dokumenta saznajemo sljedeće. Osim franjevaca iz Fojnice na taj su zbor došli i predstavnici HPS-a iz Sarajeva. Poslije Božje službe, oko 12 sati, nedaleko od crkve zbor je otvorio fra Emilijan Miličević, gvardijan franjevačkoga samostana iz Fojnice, koji je u govoru istaknuo kako je HPS jedina katolička stranka koja štiti interese katoličkoga svijeta, a iz mnoštva se čulo klicanje Stjepanu Radiću. Potom je riječ uzeo fra Vijeko Kulijer iz Fojnice koji je osudio politiku Stjepana Radića ustvrdivši da su vjera i politika povezane. Prema njegovu navodu, franjevci koji se bave vjerom, moraju se baviti i politikom, a vođa $\mathrm{Hr}$ vata mora biti dobar katolik, što Radić nije jer je uvijek napadao $\mathrm{Cr}$ kvu i Papu. Također, fra Vijeko je istaknuo da je Radić zatvarao katoličke škole te da je napustio svoj politički program, odnosno odrekao se republikanstva. Prilikom spominjanja imena Stjepana Radića iz mnoštva se klicalo: "Živio!"85 HSS je u Kraljevoj Sutjesci održao zbor na kojemu su govorili Krnjević i Šušnjić. Zboru, održanom nakon Mise, nazočilo je oko 1500 ljudi. Iz dokumenta saznajemo kako je Krnjeviću, za vrijeme njegova govora, jedan od franjevaca dobacio: "Gdje ti je republika?" Krnjević je nastavio s govorom, ali se onda javio svećenik Divić: "Što ne vičeš Krnjeviću - živjela republika?" Budući da je došlo do verbalnoga sukoba i naguravanja svećenstva, pučanstva i pristaša HSS-a, zbor je raspušten. ${ }^{86}$

Svećenstvo, posebice franjevačko, aktivno je sudjelovalo u predizbornim kampanjama kako za oblasne, tako i za skupštinske izbore. Tako fra Mijo Čujić iz Duvna 10. veljače 1927. piše provincijalu o aktivnoj ulozi u politici fra Šime Ančića koji se kandidirao za oblasne izbore na

83 ABiH, VŽSO, POV., 1927., 1810, f. 65.

84 ABiH, VŽSO, POV., 1927., 2342, f. 64

85 ABiH, VŽSO, POV., 1927., 1810, f. 5.

86 ABiH, VŽSO, POV., 1927., 1810, f. 20. 
Ivica Glibušić - Utjecaj koaliranja Hrvatske seljačke stranke...

listi HSS-a. Prema njegovu pismu, ostali župnici toga dekanata nisu aktivni u političkom smislu jer su uz HSS-ovu bile samo liste radikala i muslimana. Fra Mijo dalje naglašava kako je upoznao fra Šimuna da, prema kodeksu, ne može biti kandidiran ni ući u skupštinu te od provincijala traži upute o daljnjem postupanju. ${ }^{87}$ Sudjelovanje svećenstva bilo je još izraženije tijekom skupštinskih izbora. Domaći tisak nije štedio franjevce pa se stoga fra Dane Zubac žalio u Beograd 26. veljače 1927. ističući da to sve potječe "iz kuhinje radićevaca i izvjesnih bezvjernika u Mostaru". ${ }^{8}$ HPS je na oblasnim izborima ostvario iznimno loše rezultate pa su franjevci iz Hercegovine tražili način kako svoje kadrove postaviti na činovnička mjesta. Fra Dane u pismu upućenom fra Dominiku Mandiću traži da se na hrvatska činovnička mjesta imenuju Hrvati od povjerenja, a ne radićevci, te predlaže da se nađu novi ljudi, a ako ih nema u Hercegovini, ima ih u Sarajevu ili drugim kotarima i općinama Bosne i Hercegovine: "Što oni depolitizirani u Sarajevu rade? Razgovorite se i javi mi što i koga predlažete pa ćemo onda štošta proturati. Samo ne predložite Nuića i slične, jer ne ću da se maknem. Pisao sam Žarku da ispitate što bi se moglo moliti za Hercegovinu iz područja poljoprivrede, građevine i sve politike. U dogovoru s našim ljudima tražite osobito za one seoske vijećnike koje su dale naše kuglice za HSS. Dr. Korošec i njegovi se ljute na nas što nijesmo kod oblasnih izbora izvukli bar dva poslanika. Radi toga je postao malo nepristupačan." ${ }^{89}$ Fra Dane se čudi Slovencima koji su samo prigovarali HPS-u i franjevcima zbog loših rezultata na izborima a izostala je njihova konkretna pomoć. ${ }^{90} \mathrm{U}$ Hercegovini je 21. travnja 1927. napisan proglas Hrvatima kojega su, kako se navodi, potpisali svi važniji ljudi u Mostaru, svećenici i političari. U tom proglasu govori se o padu morala, upućuje se na Papin poziv kršćanskim narodima da se udruže i organiziraju na vjerskom i moralnom temelju, bez obzira na političko opredjeljenje. Također se navodi da se Katolička akcija pod imenom Katoličkoga narodnog saveza počela provoditi i u hrvatskom narodu te da je ta organizacija posve nepolitička. ${ }^{91}$ Dane su upute za provođenje Katoličke akcije u pojedinim župama, a poslao ih je biskupijski odbor Katoličke akci-

87 Arhiv HercegovačKe franjevačke provincije u Mostaru (dalje: AHFPM), Spisi PRovinciJe (dalje: SP), sv. 71, 1927., f. 88.

88 AHFPM, SP, sv. 73, 1927., f. 13.

89 AHFPM, SP, sv. 73, 1927., f. 16.

90 AHFPM, SP, sv. 73, 1927., f. 17.

91 AHFPM, SP, sv. 73, 1927., f. 287. 
je u Mostaru. ${ }^{92}$ HPS je 1. kolovoza 1927. uputio dopis Biskupskom ordinarijatu Mostar u kojemu traži da se fra Dominiku Mandiću iz Mostara i don Marku Zovki, župniku iz Ravnoga, prema crkvenim propisima dade dopuštenje za kandidiranje na sljedećim izborima. Naime, oni su 31. srpnja 1927. na skupštini izaslanika HPS-a iz cijele Hercegovine jednoglasno izabrani za nositelje liste u mostarskom okrugu. ${ }^{93}$ U Hercegovini je HPS vodio izbornu kampanju s ciljem diskreditiranja Radićeva HSS-a. Prigovarali su Radiću da je vodio neprincipijelnu politiku navodeći njegovu suradnju s radikalima i istupe protiv Katoličke crkve. Narodna sloboda pisala je da su zbog pogrješne HSS-ove politike mnogi radićevci, pa i cijele organizacije, prelazile u HPS. Takvu je odluku o prelasku u HPS 15. svibnja 1927. donijela i HSS-ova organizacija iz Hašljana - ljubuški kotar, s objašnjenjem da je HPS zaštitnik hrvatskih i katoličkih prava. Tijekom predizborne kampanje nije bila rijetkost da na lokalnim vjerskim proslavama dođe i do sukoba između HSS-ovaca i HPS-ovaca. Tako je na Spasovo, 26. svibnja 1927., u Čapljini došlo do sukoba između članova orlovske i sokolske organizacije. Troje je ljudi izbodeno nožem, a policija nije željela intervenirati protiv Sokola. ${ }^{94}$ Narodna sloboda navodi kako se Hrvati sve više odlučuju za HPS navodeći primjer iz Dobriča gdje je održan povjerenički sastanak na kojemu je odlučeno da će se gotovo čitav odbor Radićeve stranke pridružiti HPS-u. ${ }^{95}$ Svi ovi navodi o prelasku članstva iz jedne stranke u drugu mogu se smatrati promidžbenom kampanjom jer su ih sami rezultati izbora demantirali. U svojoj kampanji HSS je naglašavao slabu zastupljenost Hrvata na važnim pozicijama u vlasti. Nikola Precca govorio je o muslimanskom i hrvatskom pitanju u Bosni i Hercegovini. Velik problem bilo je školstvo jer su većinu učiteljskih i ravnateljskih mjesta popunjavali Srbi. ${ }^{96}$ Pavle Radić, na stranačkom sastanku HSSa u Varešu, koji se 26. svibnja 1927. održao u prostorijama Hrvatskoga pjevačkog društva "Zvijezda", govorio je protiv klerikalizma, socijalizma, komunizma i liberalizma koji šteti seljačkom pokretu. Prilikom njegova izlaganja protiv klerikalizma reagirao je upadica-

92 AHFPM, SP, sv. 73, 1927., f. 289.

93 AHFPM, SP, sv. 73, 1927., f. 67.

94 "Čitava Radićeva organizacija prelazi u Hrvatsku Pučku Stranku", u: Narodna sloboda, 21, Mostar, 28. svibnja 1927., str. 1.

95 "Hrvati, izbornici", u: Narodna sloboda, 33, Mostar, 20. kolovoza 1927., str. 1.

96 "Govor seljačkih zastupnika u proračunskoj raspravi u Beogradu", u: Dom, 13, Zagreb, 1927., str. 5. 
Ivica Glibušić - Utjecaj koaliranja Hrvatske seljačke stranke...

ma mjesni župnik Pavlović kojemu je Radić dobacio: "U Istri se satire ime hrvatsko pod okriljem Svete Stolice i oca Pape." Svi nazočni su to prihvatili negodujući prema župniku Pavloviću. Budući da nije dobio riječ, župnik Pavlović je na polasku dobacio Radiću: "Izdajice slobodnog republikanskog programa, izdajice vjere, izdajice naroda i nacije jer i hrvatsko ime hoćete da izbrišete s površine." ${ }^{17}$ Hakija Hadžić napao je svećenstvo kazavši kako ima dokaza da su s oltara zadirali u političke stvari te preporučuje da se Crkva drži po strani kada je riječ o političkim stvarima. ${ }^{98}$

HSS nije prepuštao ništa slučaju nego je još aktivnije nastavio s propagandom među Hrvatima i muslimanima. Narodu su objašnjavali da radikali ne će ispuniti svoja obećanja tako da se ne zavaravaju prelascima u tu stranku. Posebice je u mostarskom kotaru promidžba bila pojačana. Održani su sastanci u Lisama i Mokrome kojima se odzvalo više od 100 ljudi. Iznijevši program rada stranke, seljačkoga kluba i seljačkoga zastupstva, izabrani su članovi mjesnih odbora. U Mostaru je 1. rujna 1927. objavljena HSS-ova izborna lista, a za Hercegovinu nositelji lista August Košutić; za kotar Mostar Nikola Precca, Ljubuški Bariša Smoljan, Stolac Dervo Hadžioman, Konjic - Nevesinje Ilija Škobić, Lubinje - Trebinje Vide Burić, Gacko - Bileća Ivan Buconjić. ${ }^{99} \mathrm{Da}$ s podjelama unutar hrvatskoga političkog bića nije bilo gotovo, potvrdili su i izbori 1927. Naime, na tim izborima pojavio se i novi hrvatski blok, u kojem su se nalazile tri hrvatske političke stranke: HSP (frankovci), Trumbićev HFSS i Bućev HSRS. Lista HB-a u Mostaru potvrđena je 5. kolovoza 1927. s nositeljem Zvonimirom Bjelovučićem. Također, i u drugim se dijelovima $\mathrm{BiH}$ pojavila ta lista na izborima. Nositelj liste u banjolučkom izbornom okrugu bio je A. Trumbić. Cvitan Spužević suprotstavljao se HSS-u osnovavši Hrvatsku narodnu zajednicu (HNZ), a S. Janković, jedan od bivših vođa HTS-a, pokušao je u Bugojnu u srpnju 1927. osnovati novu stranku pod nazivom Hrvatska narodna stranka. ${ }^{100}$ Međutim, taj njegov potez nije naišao na odobravanje kod lokalnih Hrvata. Nikola Nikić se na tim izborima kandidirao u tuzlanskom izbornom okrugu, kao negdašnji član HTS-a koji je smatrao da će veliki dio članstva HSS-a stati na njegovu stranu. Na izborima se pojavila i Nezavisna hrvatska se-

97 ABiH, VŽSO, POV., 1927., 1015, f. 18.

98 ABiH, VŽSO, POV., 1927., 1015, f. 18.

99 ABiH, VŽSO, POV., 1927., 1803.

100 Z. Matijević, nav. dj., str. 180-181. 
ljačka stranka, što je kod Hrvata povećalo zbunjenost za koga glasovati, jer glasovanjem za više stranaka doći će do umanjenja snage vodećih političkih stranaka koje su okupljale hrvatske glasače. HPS je na izbore odlučio izići samostalno. Kada je riječ o drugoj najjačoj hrvatskoj stranci u BiH, HPS-u, objavljeni su i njihovi nositelji lista: za Mostarsko okružje Dominik Mandić, Banjalučko okružje Janko Šimrak, Travničko okružje Josip Stipančić, Sarajevsko okružje također Josip Stipančić, Tuzlansko okružje Marijan Bosančić. ${ }^{101}$

Stanje u Hercegovini nije bilo potpuno mirno što svjedoče i brojne pritužbe građana na postupanje seoskih glavara koji su u HSS-u. Teško je reći je li se radilo o promidžbi ili stvarnim prekršajima budući da $u$ policijskim izvješćima s terena nema navedenih prigovora. Iz Lipna je 7. kolovoza 1927. upućen dopis poglavaru sreza mostarskoga: "Sad je kod nas starješina Ivan Brkić, koji nije izabran narodnom voljom nego su ga radićevci kada su bili na vlasti postavili za komesara. Komesar Brkić drži da mu je bitno propagirati radićevštinu. Ni jedan od drugih partija nije siguran za imetak jer ne će da prijavljuje nasilnike. Tako se za oblasnih izbora dogodilo da je Radićeva mlađarija napala kuću Marijana Raspudića, Martina Miletića i Ivana Miličevića. Pa ni to nije prijavljeno. Širi dezinformacije tko nije radićevac da će mu se zabraniti sadnja duhana. Kod zadnje podjele kukuruza nastupao je posve stranački u korist radićevaca. Kod duhanskih dozvola pristran je bio na štetu ovih koji nisu radićevci". Pismo su potpisali Ivan Miličević, Ilija Nakić i Marijan Raspudić. ${ }^{102}$ Također, iz Kruševa je upućen dopis 8. kolovoza 1927. poglavaru sreza mostarskoga, u kojemu se govori protiv glavara Stanka Gabrića iz Kruševa. U dopisu je navedeno kako se Gabriću ne bi smjelo dati da vodi selo ni pečat u vrijeme izbora, te ga se optužuje da je prilikom fizičkoga sukoba u Čitluku, gdje je ubijen jedan čovjek Stanko Gabrić, predvodio povorku Krivodoljana kod Marinčića kuća (u nekim izvješćima se navodi Marinčića mahala). Sumnja se da napadi na kuće ljudi koji nisu u HSS-u ili ne simpatiziraju tu stranku dolaze u njegovoj organizaciji. Osim toga, navedene su i optužbe kako je ukinuo sadnju duhana nekim mještanima jer nisu bili radićevci, a kod podjele kukuruza bio je pristran. ${ }^{103}$

101 ABiH, VŽSO, POV., 1927., 1810. Usp. Z. MAtiJević, nav. dj., str. 180-181.

102 AHFP, sv. 77, 1927., f. 82.

103 AHFP, sv. 73, 1927., f. 83. Prema pisanju Narodne slobode, tučnjave i nerede počinje i vodi skupina koja se naziva Hrvatski sokol, a u službi je radićevaca. 
Ivica Glibušić - Utjecaj koaliranja Hrvatske seljačke stranke...

Nezadovoljstvo među pristašama i vodstvom HPS-a u Hercegovini nakon loših rezultata na oblasnim izborima nije prestajalo ni u kampanji za nove skupštinske izbore. To je vidljivo u prepisci između don Ilije Tomasa, fra Dominika Mandića i Žarka Vlahe tajnika HPS-a u Mostaru. Pojavljuje se ideja da se protiv velikih stranaka osnuje blok malih stranaka pod imenom "hercegovački blok", koji bi se suprotstavio HSS-u i srpskim radikalima, te da se to objavi u glasniku HPS-a. Tražio se žurni pristanak fra Dominika Mandića kako bi se prijedlog uputio vodstvu HPS-a u Zagreb. Znakovito je da u svom pismu koje je naslovio prijateljima i istomišljenicima don Ilija Tomas nagovješćuje kako slijedi još jedna borba za parlamentarne izbore. Osvrćući se na prošle oblasne izbore, don Ilija se pita što se postiglo dosadašnjim radom kada nije ostvareno gotovo ništa; imali su na protivničkoj strani Radića i sve ih je pobijedio, a obećavalo se kako će se ostvariti 12 zastupnika. Također, Tomas upućuje kritiku kako su propali zbog nesloge i da je potrebno osnovati blok malih stranaka i disidenata. Posebno se zamjera vodstvu HPS-a što stavlja neke ljude na liste a koji to nisu zaslužili jer su radili protiv HPS-ovih katolika. ${ }^{104}$

Nepravilnosti na izborima od općinskih oblasnih pa i prošlih skupštinskih bile su velike. HSS je često upućivao pritužbe na pripremu izbora, biračke popise i samu provedbu izbora jer se radilo na njihovu štetu. Neregularnosti su opsegom bile tolike da je HSS tražio poništenje izbora u potpunosti ili djelomično. Zbog prošlih iskustava u stranci su se pribojavali da će se ponoviti neregularnosti koje bi mogle znatno utjecati na konačan rezultat izbora. Problemi su se pojavili s izbornim listama jer su neki birači izbrisani, a za koje se očekivalo da bi mogli stati uz oporbu. Zastrašivanje stanovništva provodilo se prema ustaljenoj matrici o povećanju poreza, mogućnostima otkaza na što su bili najosjetljiviji državni činovnici i namještenici zaposleni u upravi, željeznici i slično. Na izborima se varalo i na način da su izborne iskaznice tzv. fantomske iskaznice, od ljudi koji više nisu živjeli na određenom mjestu, davane protivnicima HSS-a. ${ }^{105}$

Na svetkovinu svetoga Blaža u Marinčića mahali u Čitluku, iako je svećenik molio da se narod nakon Mise ne okuplja, dogodio se izgred - iz vatrenog su oružja ranjene dvije osobe, a više ih je ozlijeđeno. "Krvavi teror radićevaca u Čitluku", u: Narodna sloboda, 6, Mostar, 7. veljače 1927., str. 1.

104 AHFP, sv. 73, 1927., f. 94.

105 S. LEČEK, nav. dj., str. 19. 


\section{Uspjesi hrvatskih stranaka na skupštinskim izborima 1927.}

Prema biračkom popisu Bosna i Hercegovina imala je 548.581 birača, od toga ih je glasovanju pristupilo 406.555. Za HSS, odnosno (Narodnu seljačku stranku - privremeni naziv) NSS, glasovao je 70.801 glasač što je bilo dovoljno za dobivanje osam zastupničkih mandata. Radić je dobio dva mandata manje u odnosu na izbore 1925. godine. Sve ostale hrvatske političke stranke i samostalni kandidati osvojili su zanemariv broj glasova. ${ }^{106}$ Analizirajući podatke o broju birača od 1920. do 1927., uočava se konstantni porast. Tako je 1920. godine Bosna i Hercegovina imala 472.237 birača, 1923. - 488.498 birača, 1925. - 515.884 birača i 1927. - 548.271 birač. ${ }^{107}$ U Bosni i Hercegovini se nije povećavao broj birača kao u drugim pokrajinama, ali je on ipak bio svakim izborima malo veći. ${ }^{108}$

Skupštinski izbori 11. rujna 1927. prošli su mnogo mirnije nego prethodni. Iako je HSS izgubio značajan broj glasova i mandata u odnosu na skupštinske izbore 1925. ili 1923., i na ovim je izborima bio pobjednik na području Hrvatske te u mnogim mjestima Bosne i Hercegovine. Razlog smanjenja podrške HSS-u može se smatrati koaliranje $s$ radikalima nakon prošlih skupštinskih izbora. ${ }^{109} \mathrm{Na}$ izbore 11. rujna 1927. u cijeloj državi izišla su 2,294.352 birača, a svoje biračko pravo iskoristilo je $63 \%$ svih upisanih osoba. Radikali su dobili 734.122 glasa, od toga vladini radikali 505.735, a njihovi disidenti 228.487, HSS je dobio 381.370 glasova, Davidovićevi demokrati 375.789, Samostalna demokratska stranka 202.127, zemljoradnici 140.426, Slovenska ljudska stranka 139.932, JMO 128.335, HB 48.626, Njemačka stranka 48.032, Nezavisni radnici (komunisti) 42.865, socijalisti 23.477, Republikanska stranka 5.907, Madžarska stranka 4.232, a razne manje skupine dobile su 12.094 glasa. Pad Radićeva HSS-a nije se toliko očitovao u broju ostvarenih mandata, koliko u broju dobivenih glasova. Dok je 1925. Radićeva stranka dobila 545.466 glasova, 1927. ta se brojka spustila na 381.370 . Svakako treba naglasiti da su izbori 1927. prošli daleko mirnije i s manje političkih pritisaka nego oni 1925. kada su Radićeve pristaše bile pod stalnim

106 Z. Matijević, nav. dj., str. 180-182.

107 Statistika izbora narodnih poslanika Kraljevine Srba, Hrvata i Slovenaca, Narodna skupština kraljevine SHS, Beograd, 1928., str. 15.

108 Isto, str. 16.

109 B. Janjatović, nav. dj., str. 89. 
Ivica Glibušić - Utjecaj koaliranja Hrvatske seljačke stranke...

progonima. Dakle, Radića je 1927. ostavilo 164.096 glasača. U Bosni i Hercegovini je s 83.387 glasova Radićeva stranka pala na 68.512. Slično je bilo i s radikalima koji su 1925. osvojili 142 mandata, a 1927. svega $112 .{ }^{110}$ Usprkos svim promjenama svoje politike, Stjepan Radić je i na tim izborima uspio održati dominaciju u hrvatskom biračkom tijelu. On je program svoje stranke pokušao približiti i srpskim, i makedonskim, i crnogorskim seljacima što i opravdava naziv Narodna seljačka stranka. No, kad je pokušao postaviti svoje kandidate u Srbiji i Makedoniji, silom su ga spriječile pristaše velikosrpske politike. ${ }^{111} \mathrm{Na}$ izborima za Narodnu skupštinu 11. rujna 1927. na prostorima Bosne i Hercegovine ostvareni su sljedeći rezultati: mostarski izborni okrug imao je 72.038 glasača od kojih je glasovalo 55.037, i to 18.425 za HSS, 10.643 za JMO, 10.154 za službenu radikalnu listu, 5.885 za radikalske disidente, 3.936 za HPS (nositelj liste fra Dominik Mandić), 3.405 za listu Špire Solde, 1.740 za listu Vasilja Grđića, a 117 za listu Zvonimira Bjelovučića; za narodne zastupnike s liste HSS-a izabrani su August Košutić, Nikola Precca i Bariša Smoljan; tuzlanski izborni okrug imao je 121.589 glasača, a glasovalo ih je 89.713, i to 38.342 za JMO, 24.872 za Radikalnu stranku, $11.949 \mathrm{za}$ zemljoradnike, 8.004 za HSS, 3.152 za listu Miloša Savičića, 1.044 za listu Marijana Bosančića, 338 za listu Mate Špionjaka, a 280 za listu Nikole Nikića; HSS je dobio jedan mandat koji je pripao Đuri Basaričeku; u sarajevskom izbornom okrugu bilo je 85.975 glasača od kojih je glasovalo 65.840, i to 30.992 za JMO, 19.465 za Radikalnu stranku, 6.765 za zemljoradnike, 6.295 za HSS; HSS nije dobio nijedan mandat; u bihaćkom okrugu HSS također nije dobio mandat; banjolučki izborni okrug brojio je 118.786 glasača, od kojih je glasovalo 88.213, i to 21.920 za zemljoradnike, 21.705 za Radikalnu stranku, 13.903 za JMO i Davidovićeve demokrate, 13.543 za HSS, 10.432 za Samostalnu demokratsku stranku; s liste HSS-a izabran je Pavle Radić; u travničkom je izbornom okrugu od 87.143 glasača glasovalo njih 60.940, i to 20.312 za HSS, 16.253 za JMO, 15.245 za Radikalnu stranku, s liste HSS-a izabrani su Ivo Čelan i Karlo Glaić. ${ }^{112} \mathrm{~S}$ obzirom na izborne rezultate, HSS je, unatoč smanjenju broja glasača, izrazio zadovoljstvo svojim uspjehom. Uspoređujući broj zastupnika iz Bo-

110 R. Horvat, nav. dj., str. 352.

111 Dragoslav Ljubibratić, Buđenje Hercegovine, Sreski odbor Saveza udruženja boraca narodnooslobodilačkog rata u Mostaru, Mostar, 1966., str. 33.

112 R. Honvat, nav. dj., str. 358-359. 
sne i Hercegovine prema izbornim rezultatima iz 1923., 1925. i 1927. godine, evidentan je pad HSS-ove popularnosti. Birači su Radićevo koaliranje s radikalima kaznili na izborima. Unatoč jakom isticanju Radićeva približavanja Beogradu, HPS nije ni na tim izborima, kao ni na prethodnim, postigao značajniji uspjeh. Da je HSS unatoč koaliranju s NRS, imao znatnu potporu u Bosni i Hercegovini svjedoče izborni rezultati prema kojima je u Bosni i Hercegovini dobio osam mandata. Ako analiziramo izborne rezultate nekoliko posljednjih izbora može se zaključiti da je postojalo stabilno glasačko tijelo. Tako je HSS na izborima 1923. u BiH ostvario devet mandata, 1925. deset i 1927. osam. ${ }^{113}$ Nakon izbora i Radićeve pobjede u Hercegovini, HPSovo glasilo Narodna sloboda oštro je napadalo HSS optužujući ga da provodi teror nad Hrvatima koji nisu uz njih. Te novine su optužile HSS-ovce da su u Hercegovini prijetili svima koji su bili protiv njih navodeći primjer u Grabu, Drinovcima i Sovićima gdje su glasove namicali prijetnjama da će zapaliti kuće svima onima koji ne glasuju za Radića. ${ }^{114} \mathrm{Na}$ naslovnoj stranici objavljen je tekst u kojem se govori da radićevci teroriziraju lokalno pučanstvo. Pošteđen nije ostao ni ljubuški ni bekijski kraj, a isto je i s Brotnjom i okolicom Mostara. HPS i HSS-ovi disidenti doživjeli su težak poraz na skupštinskim izborima izgubivši podršku Hrvata na prostorima Bosne i Hercegovine. Zahvaljujući izbornim rezultatima u Bosni i Hercegovini, HSS je i dalje ostao stranka s apsolutnom podrškom hrvatskoga glasačkog tijela i u javnom životu je s pravom mogla zastupati interese Hrvata na prostoru Bosne i Hercegovine.

\section{Zaključak}

Koaliranje Hrvatske seljačke stranke s Narodnom radikalnom strankom nakon izbora 1925. godine odrazilo se smanjenjem podrške hrvatskih glasača na oblasnim i skupštinskim izborima 1927. godine na prostorima BiH. Stjepan Radić, izlaskom iz koalicije s radikalima i pojačanom izbornom promidžbom, uspio je umanjiti negativne učinke ulaska u vlast i očuvati jedinstvo stranke unatoč odlasku dijela uglednih članova HSS-a. Hrvatska pučka stranka uz pomoć dijela svećenstva Katoličke crkve nastojala je prikazati Stjepana Radića i njegovu politiku kao vrlo štetnu za hrvatske nacionalne interese. Ra-

113 Isto.

114 "Napredujemo i napredovat ćemo", u: Narodna sloboda, 37, Mostar, 17. rujna 1927., str. 1. 
dića se optuživalo za izazivanje podjela unutar Katoličke crkve, zatim za zatvaranje katoličkih škola te dodvoravanje srpskim radikalima, odustajanjem od republikanizma i priznavanjem Vidovdanskoga ustava. Unatoč tim optužbama, kada je riječ o hrvatskom biračkom tijelu unutar $\mathrm{BiH}$, HSS je uspio ostvariti pobjedu na oblasnim izborima. S obzirom na postavljena očekivanja u broju mandata HPS je doživio težak poraz. HSS je u pripremi za skupštinske izbore pojačao kampanju s ciljem zadržavanja potpore glasačkoga tijela koju je imao na oblasnim izborima. Sami izbori pokazali su smanjenje podrške HSS-u u odnosu na izbore 1923. i 1925. godine. U konačnici HSS je na prostoru $\mathrm{BiH}$ ostvario novu pobjedu unutar hrvatskoga biračkog tijela i tako nastavio dalju političku borbu za poboljšanje položaja Hrvata i muslimana na području BiH. Hrvatske stranke koje su vodile svoju kampanju na isticanju Radićevih negativnosti u političkom djelovanju, doživjele su potpuni poraz na skupštinskim izborima. Da je HSS imao znatnu potporu u BiH svjedoče izborni rezultati prema kojima je 1923. godine ostvario devet mandata, 1925. deset, a 1927. osam. Privremeno koaliranje s radikalima nije ugrozilo dominaciju HSS-a unutar hrvatskoga biračkog tijela na prostoru $\mathrm{BiH}$. 
IVICA GLIBUŠıć

\section{Influence of the coalition of Croatian Peasant Party with Serbian radicals on the 1927 election results in Bosnia and Herzegovina}

\section{Summary}

The paper deals with the results of the Croatian Peasant Party (HSS) in the 1927 regional and parliamentary elections in the area of Bosnia and Herzegovina. The paper is based on the unpublished archive materials and literature. Other Croatian political parties and dissidents of HSS in Bosnia and Herzegovina welcomed the coalition of HSS with the Serbian radicals as a suitable moment to decrease influence of HSS among Croats. Croatian People's Party (HPS) and a part of Catholic Church clergy announced the victory through emphasizing HSS involvement in the authorities with Serbian radicals, giving up on republicanism and recognizing the Vidovdan Constitution with accusations that Stjepan Radic fought against Catholic religion. Having received information on possible dispersion of members and reducing of support in the following elections, HSS leadership used more aggressive campaign visiting every place with potential voters and establishing new party branches. Despite the conflict with a part of the Catholic Church clergy in B\&H and the fact that Serbian radicals, state authorities and opposed Croatian parties sabotaged their party activities, HSS won among Croats. They got the majority support both in the regional and parliamentary elections with significantly decreased number of voters, therefore Radic was not politically endangered with the number of mandates he got and HSS was still the leading Croatian party in Bosnia and Herzegovina.

Keywords: Croatian Peasant Party; Croatian People's Party; Stjepan Radic; elections; agitation; region; parliament; Serbian radicals. 